\title{
Hyperkalemia in a patient with rhabdomyolysis and compartment syndrome -A case report-
}

\author{
Soon Eun Park, Dae-Young Kim, and Eun-sun Park \\ Department of Anesthesiology and Pain Medicine, Ulsan University Hospital, Ulsan, Korea
}

Rhabdomyolysis is a life-threatening syndrome caused by skeletal muscle injury, which results in the leakage of myoglobin, other intracellular proteins and electrolytes into the circulatory system and urine. Acute kidney injury occurs in $13-50 \%$ of patients with rhabdomyolysis, which is the principal cause of their mortality. This is to report an emergency operation performed on a patient with traumatic rhabdomyolysis and compartment syndrome who developed life-threatening hyperkalemia caused by reperfusion injury after vascular anastomosis. The patient was treated with intravascular volume expansion, sodium bicarbonate, diuretics, insulin and Continuous Renal Replacement Therapy, but the patient expired 5 days after the operation. (Korean J Anesthesiol 2010; 59: S37-S40)

Key Words: Acute renal failure, Hyperkalemia, Ischemia-reperfusion injury, Rhabdomyolysis.

Rhabdomyolysis is defined as a clinical syndrome caused by skeletal muscle injury and the ensuing deformation of muscle plasmalemma, which results in the leakage of muscle cell contents such as creatine phosphokinase, lactate dehydrogenase and myoglobin into plasma and out of cells [1]. Also, it may occur by narcotics addiction, alcoholism, infection, collagen diseases, strenuous exercise, trauma and long-term coma. Approximately 13 to $30 \%$ of patients with rhabdomyolysis may develop the complication such as acute renal failure [2,3]. In particular, the complications such as electrolyte disorders, arrhythmia and shock may lead up to death.

This is to report a patient with rhabdomyolysis, which occurred by the traumatic injury of muscle cells concurrently with the compartment syndrome, and hyperkalemia caused by the injury of the iliac artery branch and the ensuing ischemiareperfusion injury.

\section{Case Report}

A 44-year-old male, who was $175 \mathrm{~cm}$ tall and weighed 70 $\mathrm{kg}$, was admitted to the emergency room after being hit hard on his abdomen by a rope. At first, the patient complained of pain in the abdomen and both lower limbs. There was no noteworthy record in his case history, and the preoperative blood test did not show notable findings except HBsAg positive. Electrocardiography manifested sinus tachycardia and premature ventricular contraction, but there were no notable findings in the biochemical test, urinalysis and the chest

Received: December 22, 2009. Revised: 1st, February 2, 2010; 2nd, March 10, 2010. Accepted: July 21, 2010.

Corresponding author: Dae-Young Kim, M.D., Department of Anesthesiology and Pain Medicine, Ulsan University Hospital, 290-3, Jeonhadong, Dong-gu, Ulsan 682-060, Korea. Tel: 82-52-250-7248, Fax: 82-52-250-7249, E-mail: kdyangel@naver.com

(c) This is an open-access article distributed under the terms of the Creative Commons Attribution Non-Commercial License (http:// creativecommons.org/licenses/by-nc/3.0/), which permits unrestricted non-commercial use, distribution, and reproduction in any medium, provided the original work is properly cited. 
radiography. On the physical exam, pulse was not palpated in both insteps. Since computed tomography manifested the injury of superior mesenteric artery and vein in addition to small bowel laceration and the rupture of the descending colon, an emergency operation was performed.

Preanesthetic administration was not performed. Immediately before the operation, blood pressure was $80 / 57 \mathrm{mmHg}$ and heart rate was 110 beat $/ \mathrm{min}$. Peripheral oxygen saturation was $98 \%$. Electrocardiography manifested sinus tachycardia, and consciousness was clear. Anesthesia was performed through the intravenous injection of $14 \mathrm{mg}$ of etomidate, 50 $\mathrm{mg}$ of rocuronium and $0.05 \mu \mathrm{g} / \mathrm{kg} / \mathrm{min}$, and endotracheal intubation was performed after a brief manual ventilation. Until the operation was completed, $2 \mathrm{~L} / \mathrm{min}$ of oxygen, $2 \mathrm{~L} /$ min of air and 4 to 5 vol\% of desflurane were administered. The electrocardiogram, blood pressure, heart rate, peripheral oxygen saturation, capnogram, body temperature and urine volume were checked during the operation. In order to monitor intraoperative conditions and supply infusion solutions invasively, a catheter was inserted into the radial artery and a central venous catheter was inserted into the right internal jugular vein. And anesthetic intensity was monitored on the basis of the bispectral index. The arterial blood gas analysis, performed before the operation, showed $\mathrm{pH}$ of $7.33, \mathrm{PaCO}_{2}$ of $36 \mathrm{mmHg}, \mathrm{PaO}_{2}$ of $133 \mathrm{mmHg}$, base excess of $-5.7 \mathrm{mEq} / \mathrm{L}, 99 \%$ $\mathrm{SaO}_{2}$, potassium of $3.2 \mathrm{mEq} / \mathrm{L}$ and calcium of $1.02 \mathrm{mEq} / \mathrm{L}$ at $\mathrm{FiO}_{2}$ of 0.21 .

Vital signs did not change remarkably until the latter half of the operation, but the arterial blood gas analysis, performed 2 hours after anesthesia, showed $\mathrm{pH}$ of $7.39, \mathrm{PaCO}_{2}$ of $36 \mathrm{mmHg}$, $\mathrm{PaO}_{2}$ of $240 \mathrm{mmHg}$, base excess of $-3.2 \mathrm{mEq} / \mathrm{L}, 100 \% \mathrm{SaO}_{2}$, potassium of $4.4 \mathrm{mEq} / \mathrm{L}$ and calcium of $0.97 \mathrm{mEq} / \mathrm{L}$ at $\mathrm{FiO}_{2}$ of 0.5. And the analysis, performed 3 hours later, showed $\mathrm{pH}$ of 7.26, $\mathrm{PaCO}_{2}$ of $43 \mathrm{mmHg}, \mathrm{PaO}_{2}$ of $256 \mathrm{mmHg}$, base excess of $-7.4 \mathrm{mEq} / \mathrm{L}, 100 \% \mathrm{SaO}_{2}$, potassium of $5.8 \mathrm{mEq} / \mathrm{L}$ and calcium of $0.97 \mathrm{mEq} / \mathrm{L}$ at $\mathrm{FiO}_{2}$ of 0.5 . Notwithstanding that 6 units of regular insulin, $60 \mathrm{mEq}$ of sodium bicarbonate and $600 \mathrm{mg}$ of calcium chloride were intravenously injected during the operation, potassium increased continuously. And after the iliac artery, which sustained an ischemic injury in the process of the operation, was anastomosed and was reinfused, the electrocardiogram showed tall $\mathrm{T}$ waves and the arterial blood gas analysis showed $\mathrm{pH}$ of $7.26, \mathrm{PaCO}_{2}$ of $49 \mathrm{mmHg}, \mathrm{PaO}_{2}$ of $251 \mathrm{mmHg}$, base excess of $-5.3 \mathrm{mEq} / \mathrm{L}, 100 \% \mathrm{SaO}_{2}$, potassium of $6 \mathrm{mEq} / \mathrm{L}$ and calcium of $0.85 \mathrm{mEq} / \mathrm{L}$ at $\mathrm{FiO}_{2}$ of 0.5 (Table 1). Hereat, it was regarded as an electrolyte disorder of emergency and thus 5 units of regular insulin and $200 \mathrm{ml}$ of dextrose were intravenously injected $100 \mathrm{mEq}$ of sodium bicarbonate along with the use of $100 \mathrm{mEq}$ of sodium bicarbonate and the injection of $300 \mathrm{mg}$ of $3 \%$ calcium chloride. And 30 minutes later the arterial blood gas analysis was performed, which showed that $\mathrm{pH}$ of 7.30, $\mathrm{PaCO}_{2}$ of $40 \mathrm{mmHg}, \mathrm{PaO}_{2}$ of $257 \mathrm{mmHg}$, base excess of $-6.3 \mathrm{mEq} / \mathrm{L}, 100 \% \mathrm{SaO}_{2}$, potassium of 7.7 $\mathrm{mEq} / \mathrm{L}$ and calcium of $0.84 \mathrm{mEq} / \mathrm{L}$ at $\mathrm{FiO}_{2}$ of 0.5 . Resultantly, potassium increased more and tall $\mathrm{T}$ waves were continuously observed on electrocardiography. At this, 10 units of regular insulin and $30 \mathrm{ml}$ of $20 \%$ dextrose were intravenously injected simultaneously with the injection of $20 \mathrm{mg}$ of furosemide. Just then the bispectral index, which was between 30 and 40 during the operation, indicated 65 , hence $3 \mathrm{mg}$ of midaxolam was intravenously injected. On this, hypotension suddenly occurred and lasted a while. To bring up blood pressure, ephedrine was intravenously injected three times, 5, 10 and $20 \mathrm{mg}$ each. But blood pressure did not rise, and thus $5 \mu \mathrm{g} / \mathrm{kg} / \mathrm{min}$ of dopamine was instilled.

After that, the abdominal and inguinal operation was finished and the region was disinfected. After the drape was pulled back, the patient manifested the compartment syndrome and thus fasciotomy was performed urgently. Hypotension and arrhythmia continued even while fasciotomy was being performed, whereupon norepinephrine was instilled. Then blood pressure was recovered by 110 to 120 and 70 to $80 \mathrm{mmHg}$.

It took 11 hours in all to finish the operation, and aortic tansection, small bowel laceration, the segmental rupture of the

Table 1. Perioperative Changes of Blood Chemistry Analysis

\begin{tabular}{|c|c|c|c|c|c|c|}
\hline & \multirow{2}{*}{ Preop } & \multicolumn{4}{|c|}{ After induction } & \multirow{2}{*}{ Postop $30 \mathrm{~min}$} \\
\hline & & $2 \mathrm{hr}$ & $5 \mathrm{hr}$ & $9 \mathrm{hr}$ & $9.5 \mathrm{hr}$ & \\
\hline $\mathrm{FiO}_{2}$ & 0.21 & 0.5 & 0.5 & 0.5 & 0.5 & 0.8 \\
\hline $\mathrm{pH}$ & 7.33 & 7.39 & 7.26 & 7.26 & 7.30 & 7.26 \\
\hline $\mathrm{PaCO}_{2}(\mathrm{mmHg})$ & 36 & 36 & 43 & 49 & 40 & 38 \\
\hline $\mathrm{PaO}_{2}(\mathrm{mmHg})$ & 133 & 240 & 256 & 251 & 257 & 427 \\
\hline $\mathrm{HCO}_{3}{ }^{-}(\mathrm{mEq} / \mathrm{L})$ & 17.3 & 21.8 & 19.3 & 22.0 & 19 & 17.1 \\
\hline Base excess $(\mathrm{mEq} / \mathrm{L})$ & -5.7 & -3.2 & -7.4 & -5.1 & -6.3 & -9.2 \\
\hline $\mathrm{Na}^{+}(\mathrm{mEq} / \mathrm{L})$ & 135 & 137 & 140 & 135 & 133 & 130 \\
\hline $\mathrm{K}^{+}(\mathrm{mEq} / \mathrm{L})$ & 3.2 & 4.4 & 5.8 & 6.0 & 7.7 & 8.8 \\
\hline $\mathrm{Ca}^{2+}(\mathrm{mEq} / \mathrm{L})$ & 1.02 & 0.97 & 0.97 & 0.85 & 0.84 & 0.97 \\
\hline
\end{tabular}

Preop: at preoperative time, Postop 30 min: at postoperative 30 minutes. $\mathrm{PaCO}_{2}$ : arterial carbon dioxide tension, $\mathrm{PaO}_{2}$ : arterial oxygen tension. 
descending colon, the transverse rupture of the rectus muscle were diagnosed during the operation, for which aortobifemoral bypass, small bowel resection, descending colon resection and rectus muscle repair were performed. In the operating room, $8,000 \mathrm{ml}$ of plasma, $1,300 \mathrm{ml}$ of hartman solution, $9,800 \mathrm{ml}$ of physiological saline, 1,500 $\mathrm{ml}$ of crystalloid solution, 9 units of packed red blood cells and 5 units of fresh frozen plasma were administered to the patient. They totaled $24,480 \mathrm{ml}$, and blood loss and urine volume were estimated at 5,000 $\mathrm{ml}$ and 3,350 $\mathrm{ml}$ each. After the operation was completed, the patient was transferred to the intensive care unit with a tube in his airway, to whom mechanical ventilation was applied at $\mathrm{FiO}_{2} 0.8$, PIP 20 $\mathrm{cmH}_{2} \mathrm{O}$, respiratory rate of 20 breathe/min and PEEP $6 \mathrm{cmH}_{2} \mathrm{O}$.

Immediately after the patient was transferred to the intensive care unit, the potassium level increased by $8.8 \mathrm{mEq} / \mathrm{L}$, and 30 minutes later ventricular tachycardia and fibrillation were observed on the electrocardiogram and systolic blood pressure dropped by $50 \mathrm{mmHg}$. After defibrillation was applied twice at 200 joule, sinus rhythm was recovered normally, whereat $1 \mathrm{~g}$ of calcium gluconate was administered and 10 units of regular insulin and $10 \mathrm{ml}$ of $50 \%$ dextrose water were intravenously injected by mixture. And then kalimate enema was performed. The arterial blood gas analysis, performed after kalimate enema, showed $\mathrm{pH}$ of $7.30, \mathrm{PaCO}_{2}$ of $38 \mathrm{mmHg}, \mathrm{PaO}_{2}$ of $404 \mathrm{mmHg}$, base excess of $-8.4 \mathrm{mEq} / \mathrm{L}, 100 \% \mathrm{SaO}_{2}$, potassium of $7.7 \mathrm{mEq} /$ $\mathrm{L}$ and calcium of $0.98 \mathrm{mEq} / \mathrm{L}$ at $\mathrm{FiO}_{2}$ of 0.8 . After that, urine became dark-brown and continuous renal replacement therapy was performed. During the operation the manifestation of rhabdomyolysis was observed and thus conservative treatment was performed, and after the operation, it was definitely diagnosed in view of the fact that the test blood showed blood urea nitrogen of $14.9 \mathrm{mg} / \mathrm{dl}$, creatinine of $1.50 \mathrm{mg} / \mathrm{dl}$, aspartate transaminase of 3,069 IU/L, alanine transaminase of $842 \mathrm{IU} / \mathrm{L}$, lactate dehydrogenase of $14,202 \mathrm{IU} / \mathrm{L}$, creatine phosphokinase of 354,000 IU/L and serum myoglobin of 18,869 ng/ml (Table 2).

Although infusion solutions were sufficiently supplied and dopamine and norepinephrine were used, blood pressure did not rise and also multiple organ failure took a turn for the worse in tandem with renal failure accompanied by oliguria. Eventually 5 days after the operation, the patient expired.

\section{Discussion}

Rhabdomyolysis is a clinical syndrome that is caused when muscle cell contents leak into plasma due to skeletal muscle injury. External injuries, myopathy, strenuous exercise, extreme fervescence, epilepsy, narcotics addiction and toxic substances are causative of it. In this case myochrome or vasoconstrictive mediators, which come from muscle cells, may give birth to acute renal failure $[4,5]$.

Rhabdomyolysis is diagnosed in light of case history and clinical findings such as myalgia, myoma, dark-brown urine and otherwise. And it can be definitely diagnosed according to whether the creatine phosphokinase level increases 6 times or by $100 \mathrm{IU} / \mathrm{L}$ and over or whether aspartate transaminase and lactate dehydrogenase levels increase or whether mytochrome is detected from urine. Particularly, the creatine phosphokinase level is in proportion to the severity of muscular injury [6]. But muscle-related symptoms are not observed in all cases of rhabdomyolysis, and moreover it is difficult to observe such symptoms during general anesthesia. Dark-brown urine may be helpful to diagnose rhabdomyolysis, but has demerits that diagnostic sensitivity becomes low and enough time cannot be spent to remove blood myoglobin and of being unpredictable. For such reasons, dark-brown urine is not observed in all cases [7].

Table 2. Postoperative Changes of Blood Chemistry Analysis

\begin{tabular}{|c|c|c|c|c|c|c|}
\hline & \multirow{2}{*}{ Preop } & \multicolumn{5}{|c|}{ POD } \\
\hline & & 1 & 2 & 3 & 4 & 5 \\
\hline $\mathrm{Hb}(\mathrm{g} / \mathrm{dl})$ & 14.6 & 11.1 & 7.8 & 11.9 & 10.0 & 12.3 \\
\hline Plt $\left(\mathrm{K} / \mathrm{mm}^{3}\right)$ & 335 & 55 & 117 & 30 & 33 & 66 \\
\hline $\operatorname{AST}(\mathrm{IU} / \mathrm{L})$ & 31 & 699 & 4,232 & 6,600 & 5,700 & 14,200 \\
\hline ALT (IU/L) & 19 & 190 & 1,393 & 1,856 & 1,721 & 3,288 \\
\hline BUN (mg/dl) & 12.8 & 14.0 & 22.1 & 22.0 & 22.8 & 16.7 \\
\hline $\mathrm{Cr}(\mathrm{mg} / \mathrm{dl})$ & 0.94 & 1.19 & 1.66 & 1.54 & 1.50 & 0.50 \\
\hline $\mathrm{Na}^{+}(\mathrm{mEq} / \mathrm{L})$ & 136 & 141 & 134 & 136 & 138 & 139 \\
\hline $\mathrm{K}^{+}(\mathrm{mEq} / \mathrm{L})$ & 4.0 & 8.3 & 6.9 & 6.0 & 4.6 & 2.9 \\
\hline $\mathrm{Ca}^{2+}(\mathrm{mEq} / \mathrm{L})$ & 1.08 & 1.15 & 1.03 & 1.03 & 1.02 & 1.00 \\
\hline $\mathrm{LDH}(\mathrm{IU} / \mathrm{L})$ & - & 3,574 & 142,02 & 23,430 & 18,600 & 37,100 \\
\hline CK $(\mathrm{IU} / \mathrm{L})$ & - & 100,000 & 354,000 & 39,200 & 310,400 & 255,700 \\
\hline Myoglobin (ng/ml) & - & 15,912 & 16,869 & 3,236 & 8,310 & - \\
\hline
\end{tabular}

Preop: at preoperative time, POD: postoperative day, Hb: hemoglobin, Plt: platelet, AST: aspartate transaminase, ALT: alanine transaminase, BUN: blood urea nitrogen, Cr: creatinine, LDH: lactate dehydrogenase, CK: creatine phosphokinase. 
In the present case, the traumatic injury of muscle cells, ischemia-reperfusion injury caused by the injury of the iliac artery branch, and the compartment syndrome occurred in combination with each other, and as a result uncontrolled hyperkalemia came about. Trauma could be considered as a causative factor, but particular findings were not observed on the preoperative hemodynamic test and also dark-brown urine was not observed during the operation; resultingly, it was difficult to diagnose rhabdomyolysis early. The present case was suspected to be rhabdomyolysis during the operation, and thus conservative treatment was performed. However, the definite diagnosis could be made after the operation as only then did dark-brown urine come out and myoglobin and muscle enzymes such as aspartate transaminase, creatine phosphokinase and lactate dehydrogenase suddenly increase.

There has not been clear elucidation on the mechanism where rhabdomyolysis brings about acute renal failure, which is presumed to be related with tubular obstruction caused by myoglobin, vasoconstriction caused by myoglobin's inhibiting endothelial relaxing factors, free radical formation toxicity caused by the ferrous compound, i.e., the metabolite of myoglobin $[8,9]$.

The treatment of rhabdomyolysis is the prevention of acute renal failure. The inducers should be removed rapidly and the treatment should be focused on the prevention of complications. It is known that infusion solutions should be supplied sufficiently in addition to the use of mannitol and furosemide in order that urine volume can be maintained at 200 to $300 \mathrm{ml} / \mathrm{hr}$, and that sodium bicarbonate should be intravenously injected for alkaline diuresis [10]. However, what should not be overlooked is that the oversupply of infusion solutions may cause pulmonary edema. In the case of persistent and irresponsive hyperkalemia or persistent metabolic acidosis or fluid overload, it is recommendable to perform hemodialysis $[2,11,12]$.

The present case was suspected to be rhabdomyolysis on the authority of the traumatic injury of muscle cells, the compartment syndrome and clinical symptoms such as persistent metabolic acidosis, hyperkalemia, hypokalemia and otherwise. During the operation, sodium bicarbonate was used to treat metabolic acidosis and prevent acute renal failure, and urine volume was maintained at $300 \mathrm{ml} / \mathrm{hr}$. The potassiumbearing infusion solutions were not used to treat hyperkalemia, and potassium, insulin and dextrose were injected to control hyperkalemia. After hyperkalemia was controlled to some degree, the iliac artery, which was injured in the process of the operation, was anastomosed. At the moment when the iliac artery was made to reperfuse, potassium, accumulated by ischemia, flew in by systemic circulation, which was thought to cause serious hyperkalemia and arrhythmia. There was a need to perform hemodialysis, but the operation came to the finish. Such being the case, hemodialysis was planned to be performed in the intensive care unit and conservative treatment was performed prior to it, which was causative of life-threatening arrhythmia and renal failure.

In conclusion, it is advisable for anesthesiologists who are faced with traumatic emergency operations frequently to look at the possibility of rhabdomyolysis though suspicious findings are not observed. In the event a case that is suspected to be rhabdomyolysis, the urinalysis and blood test should be performed with rapidity and it can be diagnosed early and treated aggressively. In case rhabdomyolysis is not diagnosed early and treated aggressively, it may function as a risk factor for acute renal failure and threaten the patient's life. Thus, anesthesiologists have need to get everything in readiness all the time.

\section{References}

1. Lima RS, da Silva Junior GB, Liborio AB, Daher Ede F. Acute kidney injury due to rhabdomyolysis. Saudi J Kidney Dis Transpl 2008; 19: 721-9.

2. Holt SG, Moore KP. Pathogenesis and treatment of renal dysfunction in rhabdomyolysis. Intensive Care Med 2001; 27: 80311.

3. Melli G, Chaudhry V, Cornblath DR. Rhabdomyolysis: an evaluation of 475 hospitalized patients. Medicine (Baltimore) 2005; 84: 377-85.

4. Kim HY, Choi SO, Shin SJ, Kim YK, Han BG, Park SJ, et al. Analysis of 250 cases of rhabdomyolysis. Korean J Nephrol 1994; 13: 810-7.

5. Lee JS, Choi GB, Yoon KI. Clinical analysis of acute renal failure accompanying rhabdomyolysis. Korean J Nephrol 1993; 12: 609-15.

6. Oda J, Tanaka H, Yoshioka T, Iwai A, Yamamura H, Ischikawa K, et al. Analysis of 372 patients with crush syndrome caused by the Hanshine-Awaji earthquake. J Trauma 1997; 42: 470-5.

7. Bosch X, Poch E, Grau JM. Rhabdomolysis and acute kidney injury. N Engl J Med 2009; 361: 62-72.

8. Edwards DH, Griffith TM, Ryley HC, Henderson AH. Haptoglobinhemoglobin complex in human plasma inhibits endothelium dependent relaxation: evidence that endothelium derived relaxing factor acts as a local autocoid. Cardiovasc Res 1986; 20: 549-56.

9. Halliwell B, Gutteridge JM. Free radicals in biology and medicine. Oxford, Clarendon Press. 1985, p 118.

10. Lane R, Philips M. Rhabdomyolysis. BMJ 2003; 327: 115-6.

11. Vanholder R, Sever MS, Erek E, Lameire N. Rhabdomyolysis. J Am Soc Nephrol 2000; 11: 1553-61.

12. Lameire N, Van Biesen W, Vanholder R. Acute renal failure. Lancet 2005; 365: 417-30. 